\title{
Article \\ Expanding the Neurological Phenotype of Ring Chromosome 10 Syndrome: A Case Report and Review of the Literature
}

\author{
Jacopo Pruccoli ${ }^{1,2}{ }^{(}$, Claudio Graziano $^{3}{ }^{-0}$, Chiara Locatelli $^{4}$, Lucia Maltoni ${ }^{5}$, Hodman Ahmed Sheikh Maye ${ }^{6}$ \\ and Duccio Maria Cordelli 1,2,*(D) \\ 1 Child Neurology and Psychiatry Unit, IRCCS Istituto delle Scienze Neurologiche di Bologna, \\ 40138 Bologna, Italy; jacopo.pruccoli@studio.unibo.it \\ 2 Dipartimento di Scienze Mediche e Chirurgiche (DIMEC), University of Bologna, 40138 Bologna, Italy \\ 3 U.O. Genetica Medica, IRCCS Azienda Ospedaliero-Universitaria di Bologna, 40138 Bologna, Italy; \\ claudio.graziano@unibo.it \\ 4 Neonatal Intensive Care Unit, S. Orsola Malpighi Hospital, 40138 Bologna, Italy; chiara.locatelli@aosp.bo.it \\ 5 Child Neurology and Psychiatry Unit, Azienda USL della Romagna, 48121 Ravenna, Italy; \\ lucia.maltoni3@unibo.it \\ 6 IRCCS Istituto delle Scienze Neurologiche di Bologna, UOC Neuroradiologia, 40139 Bologna, Italy; \\ hodman.ahmedsheikhmaye@isnb.it \\ * Correspondence: ducciomaria.cordelli@unibo.it
}

check for updates

Citation: Pruccoli, J.; Graziano, C.; Locatelli, C.; Maltoni, L.; Sheikh

Maye, H.A.; Cordelli, D.M.

Expanding the Neurological

Phenotype of Ring Chromosome 10 Syndrome: A Case Report and Review of the Literature. Genes 2021, 12, 1513. https://doi.org/10.3390/ genes12101513

Academic Editor: Diego Centonze

Received: 1 September 2021

Accepted: 24 September 2021

Published: 26 September 2021

Publisher's Note: MDPI stays neutral with regard to jurisdictional claims in published maps and institutional affiliations.

Copyright: (c) 2021 by the authors. Licensee MDPI, Basel, Switzerland. This article is an open access article distributed under the terms and conditions of the Creative Commons Attribution (CC BY) license (https:// creativecommons.org/licenses/by/ $4.0 /)$

\begin{abstract}
Ring chromosome 10 [r(10)] syndrome is a rare genetic condition, currently described in the medical literature in a small number of case report studies. Typical clinical features include microcephaly, short stature, facial dysmorphisms, ophthalmologic abnormalities and genitourinary malformations. We report a novel case of $\mathrm{r}(10)$ syndrome and review the neurological and neuroradiological phenotypes of the previously described cases. Our patient, a 3 year old Italian girl, represents the 20th case of $\mathrm{r}(10)$ syndrome described to date. Intellectual disability/developmental delay (ID/DD), microcephaly, strabismus, hypotonia, stereotyped/aggressive behaviors and electroencephalographic abnormalities were identified in our patient, and in a series of previous cases. A brain MRI disclosed a complex malformation involving both the vermis and cerebellar hemispheres; in the literature, posterior cranial fossa abnormalities were documented by CT scan in another case. Two genes deleted in our case (ZMYND11 in 10p and EBF3 in 10q) are involved in autosomal dominant neurodevelopmental disorders, characterized by different expressions of brain and posterior cranial fossa abnormalities, ID/DD, hypotonia and behavioral problems. Our case expands the neurological and neuroradiological phenotype of $r(10)$ syndrome. Although $r(10)$ syndrome represents an extremely rare condition, with a clinical characterization limited to case reports, the recurrence of specific neurological and neuroradiological features suggests the need for specific genotype-phenotype studies.
\end{abstract}

Keywords: ring chromosome 10; r10; r(10); neurology; neuroradiology; magnetic resonance imaging (MRI); ZMYND11; EBF3

\section{Introduction}

Ring chromosome $10[\mathrm{r}(10)]$ syndrome represents a rare genetic condition, resulting from de novo breakage of chromosome 10 and subsequent intrachromosome fusion during meiosis or initial postzygotic mitosis. It is currently reported in 19 unrelated patients in the medical literature, but most patients were described before the introduction of chromosomal microarray technology, and the precise definition of deleted regions and encompassed genes is lacking. Typical clinical features include intellectual disability and/or developmental delay (ID/DD), microcephaly, short stature, facial dysmorphisms, ophthalmologic abnormalities and genitourinary malformations [1-17]. In constitutional ring chromosomes, the regions involved by the breakage, the amount of lost information, and the level of mosaicism resulting from the unstable nature of the ring upon cell division may vary each 
time, causing patients with a seemingly analogous ring chromosome to display diverse clinical pictures [18]. We report the case of a novel patient with $\mathrm{r}(10)$ syndrome, presenting a review of previously described neurological and neuroradiological phenotypes.

\section{Case Presentation}

Our patient is a 3 year, 10 month old girl born to non-consanguineous, Italian parents. Family history revealed a congenital ventricular septal defect in the mother.

A first trimester combined prenatal screening (assessing serum pregnancy-associated plasma protein-A (PAPP-A) and human chorionic gonadotropin (HCG), and ultrasound evidence of nuchal translucency) was unremarkable. Intrauterine growth retardation was observed at 28 weeks of gestational age. No exposure to radiation or any drug was registered. She was born at 35 weeks, 4 days of gestational age by caesarean section for podalic version. At birth, the patient presented diffused hypotonia with impaired suction, bilateral pes valgus and a systolic heart murmur. Weight at birth was $1.610 \mathrm{~g}(-2 \mathrm{SD})$; length $42 \mathrm{~cm}(-2 \mathrm{SD})$; and head circumference $29 \mathrm{~cm}(-2 \mathrm{SD})$ [19]. APGAR scores were 5 at $1^{\prime}$, and 9 at $5^{\prime}$. At birth, she was hospitalized for 20 days in a Neonatal Intensive Care Unit for respiratory distress, neonatal jaundice and hypocalcemia. Cerebral ultrasounds revealed ventricular asymmetry (left prominence). Cardiological examination showed ostium secundum atrial septal defect, patent ductus arteriosus and left ventricular dilation with moderate systolic dysfunction, requiring treatment with furosemide and captopril. Given the evidence of recurrent aspiration pneumonias occurring since her infancy, multiple chest radiographs were performed, which did not reveal potentially responsible malformations in the upper or lower airways. Repeated upper gastrointestinal tract radiographies were then performed, documenting multiple episodes of gastroesophageal reflux, followed by aspiration into the upper airways. The cough reflex was unremarkable, and no malformation of upper or lower gastrointestinal tract was documented. Neonatal otoacoustic emissions were unremarkable.

Cytogenetic analysis of blood lymphocytes revealed an apparently non-mosaic ring chromosome 10 [46,XX,r(10) (p15q26.1)]. Fifty metaphase spreads were analyzed in each experiment to exclude mosaicism. FISH analysis with chromosome 10 subtelomeric probes revealed secondary aberrations in $40 \%$ of the examined mitoses (mainly a ring chromosome 10 with conserved subtelomeric regions and a derivative chromosome 10 with two subtelomeric $\mathrm{p}$ and one $\mathrm{q}$ region on the short arm). Chromosomal microarray analysis (SurePrint G3 ISCA v2 CGH 8x60K, Agilent Technologies) allowed a better definition of the breakpoints: arr[GRCh37] 10p15.3p15.1(136361_4212930) × 1,10q26.13q26.3(127294919_135434178) × 1, indicating an approximately $4.1 \mathrm{Mb}$ deletion in $10 \mathrm{p}$ and $8.2 \mathrm{Mb}$ deletion in $10 \mathrm{q}$. These deletions encompass many protein-coding genes, but we highlight that two deleted genes (ZMYND11 in 10p and EBF3 in 10q) are involved in autosomal dominant neurodevelopmental disorders, with haploinsufficiency as the accepted pathogenic mechanism. We thus believe that ZMYND11 and EBF3 are likely the major drivers of the neurological phenotype in this patient. The full list of the genes encompassed by the deletion documented in our patient are reported in Table 1, together with their discussed functions and phenotypes [20-22]. 
Table 1. Genes interested by deletions identified in the present case.

\begin{tabular}{|c|c|c|c|c|c|c|}
\hline Deletion & Gene $^{a}$ & $\begin{array}{l}\text { Gene OMIM } \\
\text { Number }\end{array}$ & Transmission & Function & $\begin{array}{c}\text { Phenotype and } \\
\text { Phenotype OMIM } \\
\text { Number }\end{array}$ & Discussion \\
\hline 1 & ZMYND11 & 608668 & $\mathrm{AD}$ & Zinc finger & $\begin{array}{c}\text { OMIM } 616083 \\
\text { Mental retardation, } \\
\text { autosomal } \\
\text { dominant } 30\end{array}$ & $\begin{array}{c}\text { ID/DD and } \\
\text { behavioral } \\
\text { problems } \\
\text { documented in the } \\
\text { present case; } \\
\text { differences in MRI } \\
\text { abnormalities }\end{array}$ \\
\hline 1 & WDR37 & 618586 & $\mathrm{AD}$ & $\begin{array}{c}\text { Protein } \\
\text { involved in cell } \\
\text { cycle, } \\
\text { transduction } \\
\text { and apoptosis }\end{array}$ & $\begin{array}{l}\text { OMIM } 618652 \\
\text { Neuro-oculo- } \\
\text { cardio-genito- } \\
\text { urinary } \\
\text { syndrome }\end{array}$ & $\begin{array}{l}\text { ID/DD with } \\
\text { prevalent language } \\
\text { impairment, } \\
\text { hypotonia, } \\
\text { microcrania and } \\
\text { CNS abnormailities } \\
\text { partially overlap } \\
\text { the present case } \\
\text { major heart and eye } \\
\text { abnormalities }\end{array}$ \\
\hline 1 & PITRM1 & 618211 & $\mathrm{AR}$ & Metallopeptidase & $\begin{array}{l}\text { OMIM } 619405 \\
\text { Spinocerebellar } \\
\text { ataxia, autosomal } \\
\text { recessive } 30\end{array}$ & $\begin{array}{l}\text { DD +/ - ID, ataxia, } \\
\text { behavioral } \\
\text { abnormalities. } \\
\text { Cerebellar atrophy. } \\
\text { Progressive } \\
\text { condition. }\end{array}$ \\
\hline 2 & MMP21 & 608416 & $\mathrm{AR}$ & $\begin{array}{l}\text { Matrix metallo- } \\
\text { proteinase }\end{array}$ & $\begin{array}{c}\text { OMIM } 616749 \\
\text { Autosomal visceral } \\
\text { heterotaxy-7 }\end{array}$ & $\begin{array}{l}\text { Major cardiac } \\
\text { abnormalitites } \\
\text { (minor cardiac } \\
\text { abnormalities in } \\
\text { the present case). } \\
\text { Situs inversus }\end{array}$ \\
\hline 2 & EBF3 & 607407 & $\mathrm{AD}$ & $\begin{array}{c}\text { Trasciption } \\
\text { factor inducing } \\
\text { apoptosis and } \\
\text { cell cycle arrest }\end{array}$ & $\begin{array}{l}\text { OMIM } 617330 \\
\text { Hypotonia, ataxia, } \\
\text { and delayed } \\
\text { development } \\
\text { syndrome }\end{array}$ & $\begin{array}{l}\text { Hypotonia, ID/DD, } \\
\text { ataxia; in a few } \\
\text { cases, cerebellar } \\
\text { vermian } \\
\text { hypoplasia, } \\
\text { partially } \\
\text { overlapping the } \\
\text { present case }\end{array}$ \\
\hline 2 & ECHS1 & 602292 & $\mathrm{AR}$ & $\begin{array}{l}\text { short-chain } \\
\text { enoyl-CoA } \\
\text { hydratase, } \\
\text { catalyzing } \\
\text { mitochondrial } \\
\text { fatty acid } \\
\beta \text {-oxidation }\end{array}$ & $\begin{array}{l}\text { OMIM } 616277 \\
\text { Mitochondrial } \\
\text { short-chain } \\
\text { enoyl-CoA } \\
\text { hydratase-1 } \\
\text { deficiency }\end{array}$ & $\begin{array}{l}\text { DD, hyptonia, } \\
\text { brain atrophy and } \\
\text { brain lesions } \\
\text { in the basal ganglia. } \\
\text { Progressive } \\
\text { condition }\end{array}$ \\
\hline
\end{tabular}

Deletion 1: $\operatorname{del}(10)(p 15.3 p 15.1) ;$ deletion 2: $\operatorname{del}(10)(q 26.13 q 26.3)$. Abbreviations: AD: autosomal dominant; AR: autosomal recessive; CNS: central nervous system; DD: developmental delay; ID: intellectual disability; MRI: magnetic resonance imaging. ${ }^{\text {a: }}$ Online Mendelian Inheritance in Man (OMIM) (https:/ / www.omim.org) (accessed on 19 September 2021) [20]; DECIPHER (https:/ /www.deciphergenomics. org (accessed on 19 September 2021)) [21]; GeneCards (https: / / www.genecards.org (accessed on 19 September 2021)) [22].

Parental analysis was not performed, in accordance with the caregivers of the patient. The microarray profile for this patient is reported in Figure 1. 


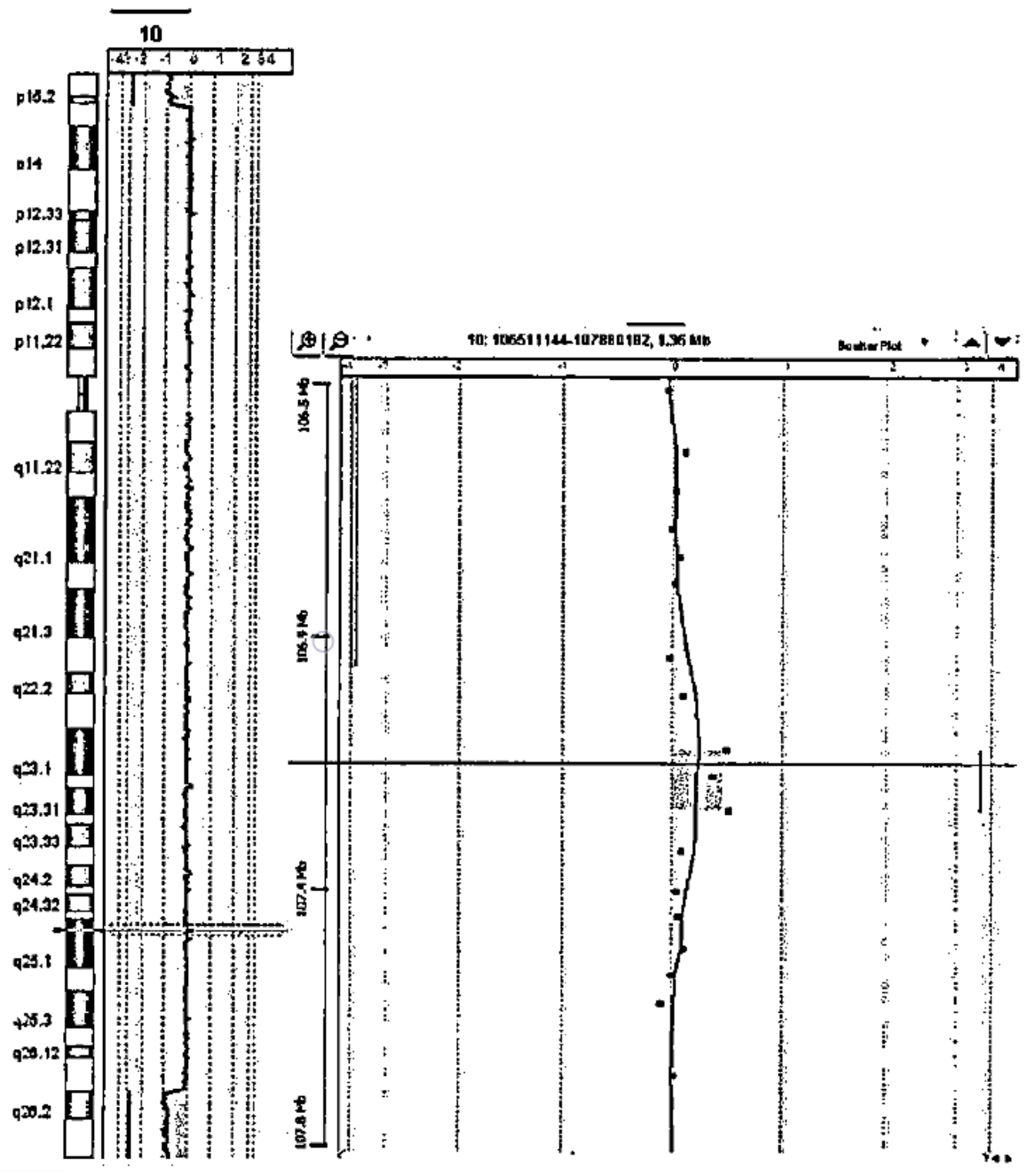

Figure 1. Microarray profile of the present case.

For markedly reduced growth rates, and growth hormone (GH) deficiency, $\mathrm{GH}$ treatment was started at the age of 3 years. At 3 years, 2 months, before the start of $\mathrm{GH}$, body weight was $9.0 \mathrm{~kg}(<2.5 \mathrm{SD})$, height was $77.8 \mathrm{~cm}(<2.5 \mathrm{SD})$, and head circumference was $42 \mathrm{~cm}(<2.5 \mathrm{SD})$. Her growth improved after 8 months of GH therapy, reaching a body weight of $12.5 \mathrm{~kg}(<2 \mathrm{SD})$ and height of $87 \mathrm{~cm}(<2.5 \mathrm{SD})$. Lumbar kyphosis, abduction and external rotation of the hips, and pes valgus, required the adoption of individualized postural systems. Ophthalmological evaluations revealed myopia and convergent strabismus.

Repeated neurological evaluations of our patient showed severe intellectual disability and global developmental delay. Head control was gained at 6 months. At 12 months of life, she reached an autonomous sitting position. At around 3 years she started to keep upright position autonomously. At 3 years, 10 months, our patient maintains an upright position and walks if supported. Spoken language is absent and the declarative pointing gestures have not been acquired. Augmentative and alternative communication was recently started. She frequently presents body rocking stereotypies; acute, paroxysmal hairpulling stereotypies are occasionally evident. Significant traction alopecia occurred as a consequence of these stereotypies, requiring hair cutting. Divergent, congenital strabismus persisted since the first months of life with alternating esophoria. Remaining cranial nerves are clinically unremarkable. Micrognathia is evident. She presents axial hypotonia and deep tendon reflexes are bilaterally brisk. She uses both hands to manipulate and play with objects, showing good interactions with caregivers and examiners. A sleep and wake EEG performed at 1 year, 4 months, revealed diffuse rapid rhythms, prevalent on temporo- 
parietal regions of both hemispheres. The background activity showed posterior bilateral slowing, more evident on the parieto-occipital region of the right hemisphere and at the vertex. These elements persisted at 3 years. No defined paroxysmal activity was identified, and our patient has never presented any febrile or non-febrile seizures.

Two brain magnetic resonance imaging (MRI) studies, performed on a $1.5 \mathrm{~T}$ scanner (Achieva, Philips) when the patient was 2 years, and 3 years and 10 months old, respectively, revealed the presence of several abnormalities, mostly involving structures of the posterior cranial fossa. The cerebellum appeared dysplastic with abnormal foliation, especially the anterior lobe, and a mild asymmetry of the hemispheres was present. The vermis was mildly hypoplastic, with a prevalent reduction in height rather than anteroposterior diameter [23]. Pontine hypoplasia with abnormally increased rostrocaudal length of the medulla and midbrain with respect to the pons was present. Corpus callosum was hypoplastic with reduced thickness of the rostrum and splenium, whose measurements were below the 3rd percentile, and the genu and isthmus thickness were reduced compared to the median values [24]. Lateral ventricles were enlarged and dysmorphic, presenting wavy margins and a widened aspect of the frontal horns. Periventricular white matter appeared reduced in volume. The main findings of the brain MRI are reported in Figure 2.

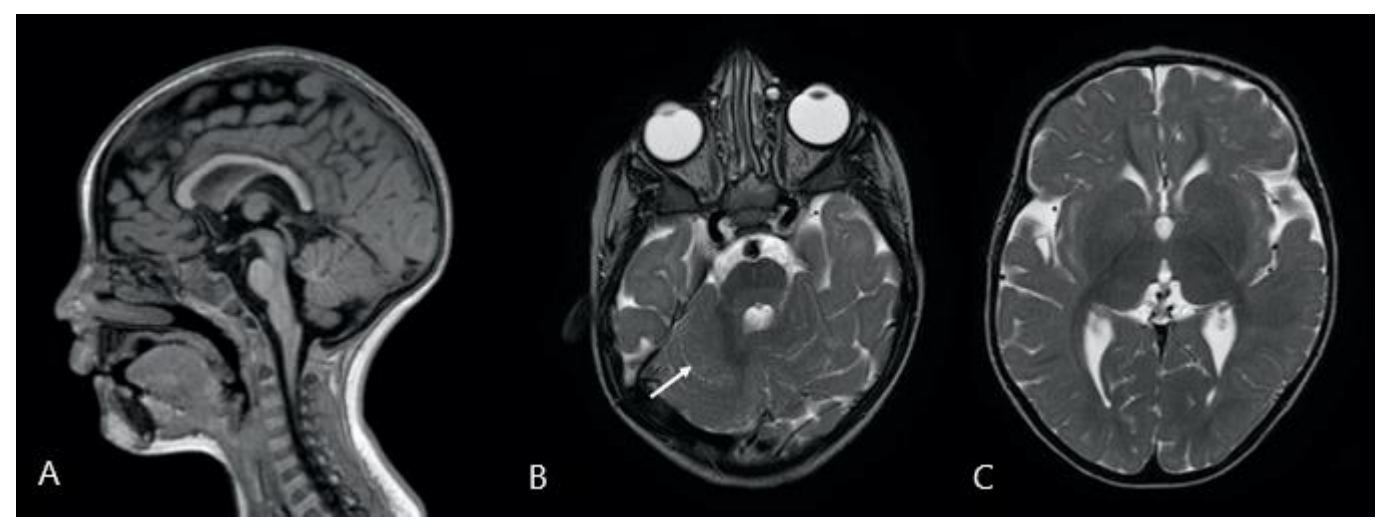

Figure 2. Description: (A): 3D-T1-weighted midline sagittal image shows a reduced thickness of the corpus callosum; the pons appears to be small and short compared to the length of the midbrain and medulla oblongata. The vermis is slightly hypoplastic with a prevalent reduction in height. (B,C): Turbo Spin Echo T2-weighted axial images showing (B) dysplastic cerebellum with abnormal foliation (white arrow), and (C) dysmorphic lateral ventricles, especially the frontal and occipital horns.

\section{Search Strategy and Analysis of Literature}

Citations were identified through PubMed, Web of Science and Google scholar searches using the search terms (including variations), "Ring chromosome 10 syndrome", "Ring 10 neurology", "Ring 10 neuroradiology" and "Ring 10 electroencephalography", combined with study filters for original research, case reports and case series. The identified reports were screened manually for patients fulfilling inclusion criteria (Ring chromosome 10 syndrome). Additional articles were identified from the reference lists of identified papers. Only papers published in English were reviewed. Nineteen previously published cases were identified in the literature [1-17].

\section{Results}

Together with the presented case, 20 cases were identified. The main findings are summarized in Table 2. Fifteen subjects presented ID/DD. Microcephaly was reported in 15 , and eight patients presented strabismus. Hypotonia was identified in nine patients. An EEG description was provided in six cases, of which one patient presented EEG abnormalities. One patient had a history of seizures time linked to progressive renal failure and three patients presented febrile seizures. Five patients were studied with a brain computerized 
tomography (CT), whereas in $2 / 20$ cases a brain MRI was performed. In one case, a CT scan documented a Dandy-Walker variant.

Table 2. Neurological phenotype of described patients with ring 10 chromosome syndrome.

\begin{tabular}{|c|c|c|c|c|c|c|c|c|c|c|}
\hline Case & $\begin{array}{l}\text { Breakpoints } \\
\text { (10p and 10q) }\end{array}$ & ID/DD & Microcephaly & Strabismus & Hypotonia & Other & EEG & Seizures & $\begin{array}{l}\text { Brain } \\
\text { Imaging }\end{array}$ & Reference \\
\hline 1 & p14, q25 & + & + & & & & & & & $\begin{array}{c}\text { Lansky } \\
\text { et al. (1977) }\end{array}$ \\
\hline 2 & p15, q26 & + & + & + & & Hyperactivity & & & & $\begin{array}{c}\text { Sparkes } \\
\text { et al. (1978) }\end{array}$ \\
\hline 3 & p15, q25 & & + & & + & & & & Normal CT & $\begin{array}{l}\text { Fryns et al. } \\
\text { (1978) }\end{array}$ \\
\hline 4 & p15, q26 & + & + & & + & & & & & $\begin{array}{c}\text { Simoni } \\
\text { et al. (1979) }\end{array}$ \\
\hline 5 & $\mathrm{p} 15, \mathrm{q} 26$ & + & + & + & & & Normal & FS & Normal US & $\begin{array}{c}\text { Tsukino } \\
\text { et al. (1980) }\end{array}$ \\
\hline 6 & p15.3, q26.1 & + & + & & + & & $\begin{array}{l}\text { Occipital } \\
\text { SW; diffuse } \\
\text { fast } \\
\text { activity; } \\
\text { paroxys- } \\
\text { mal } \\
\text { general- } \\
\text { ized } \\
\text { SW }\end{array}$ & & Normal CT & $\begin{array}{c}\text { Michels } \\
\text { et al. (1981) }\end{array}$ \\
\hline 7 & p15, q26 & + & + & & & & & & & $\begin{array}{c}\text { Serville } \\
\text { et al. (1982) }\end{array}$ \\
\hline 8 & p15, q26 & + & + & & & & Normal & FS & & $\begin{array}{l}\text { Nakai et al. } \\
\text { (1983) }\end{array}$ \\
\hline 9 & p15.3, q26.3 & + & & + & & & Normal & & Normal CT & $\begin{array}{c}\text { Kondo } \\
\text { et al. (1984) }\end{array}$ \\
\hline 10 & & & & & + & & & & & Zorn (1984) \\
\hline 11 & p15, q26 & + & + & + & & & & & & $\begin{array}{c}\text { Shapiro } \\
\text { et al. (1985) }\end{array}$ \\
\hline 12 & p15.3, q26.3 & + & & & & & Normal & & & $\begin{array}{l}\text { Kishi et al. } \\
\text { (1985) }\end{array}$ \\
\hline 13 & p13-15, q26 & + & + & & + & & & Convulsions & & $\begin{array}{l}\text { Calabrese } \\
\text { et al. (1994) }\end{array}$ \\
\hline 14 & p15, q26 & + & + & & & MDD & & & Normal CT & $\begin{array}{l}\text { Concolino } \\
\text { et al. (2003) }\end{array}$ \\
\hline 15 & p15.3, q26.12 & & + & & + & $\begin{array}{l}\text { Horner } \\
\text { Syndrome }\end{array}$ & & & $\begin{array}{l}\text { Normal } \\
\text { MRI }\end{array}$ & $\begin{array}{l}\text { Gunnarsson } \\
\text { et al. (2009) }\end{array}$ \\
\hline 16 & p14, q26.3 & & Macrocephaly & & & & & & & $\begin{array}{l}\text { Christopoulou } \\
\text { et al. (2012) }\end{array}$ \\
\hline 17 & p15.3, q26.2 & & + & + & & & & & & $\begin{array}{l}\text { Guilherme } \\
\text { et al. (2013) }\end{array}$ \\
\hline 18 & p15.3, q26.13 & + & & + & + & & & FS & $\begin{array}{l}\text { Dandy- } \\
\text { Walker } \\
\text { variant at } \\
\text { CT }\end{array}$ & $\begin{array}{l}\text { Guilherme } \\
\text { et al. (2013) }\end{array}$ \\
\hline 19 & p15.1, q26.1 & + & + & + & + & Stereotypies & & & $\begin{array}{c}\text { US: dilated } \\
\text { ventricles, } \\
\text { then } \\
\text { normal }\end{array}$ & $\begin{array}{l}\text { Čiuladaitè } \\
\text { et al. (2015) }\end{array}$ \\
\hline 20 & p15, q26.1 & + & + & + & + & Stereotypies & $\begin{array}{l}\text { Temporo- } \\
\text { parietal BL } \\
\text { rapid } \\
\text { rhythms, } \\
\text { posterior } \\
\text { slowing }\end{array}$ & None & $\begin{array}{l}\text { MRI: } \\
\text { posterior } \\
\text { cranial } \\
\text { fossa and } \\
\text { CC abnor- } \\
\text { malities }\end{array}$ & $\begin{array}{l}\text { Present } \\
\text { case }\end{array}$ \\
\hline
\end{tabular}

Abbreviations: BL: bilateral; CT: computerized tomography; CC: corpus callosum; DD: developmental delay; EEG: electroencephalography; FS: febrile seizures; ID: intellectual disability; MDD: major depressive disorder; MRI: magnetic resonance imaging; US: ultrasounds; SW: slow waves. Note: "+" indicates documented findings, blank spaces indicate missing data. 


\section{Discussion}

Ring 10 chromosome syndrome is an uncommon disease, with 19 previously reported cases in literature. Clinical neurological and neuroradiological features presented in our patient partially resemble those documented in a small series of previously documented cases.

Clinically, our patient presents ID/DD. ID and DD, from mild to severe, have been reported in nearly all described patients with $\mathrm{r}(10)$ syndrome surviving across childhood. As an exception, case $n^{\circ} 17$ presented normal development with no reported ID but died at age 15 years due to cardiac arrest [16].

Since her birth, our patient presented microcephaly. Microcephaly is a relatively stable characteristic across $\mathrm{r}(10)$ cases with different genetic involvement, as it is reported among $15 / 20$ patients. Notably, case $n^{\circ} 16$, an autopsy study of a 27 gestational week old fetus, represents the only case of $\mathrm{r}(10)$-associated macrocephaly [15]. Concerning ophthalmological involvement, our patient presents convergent strabismus and myopia, two conditions previously reported in patients with $\mathrm{r}(10)$ syndrome $(8 / 20$ and $4 / 20$, respectively). Possible coexistence of choroid coloboma, macular hypoplasia or Horner Syndrome confirm the need to perform an ophthalmological screening in these patients. Truncal hypotonia, as revealed by neurological examination of our patient, is frequently the most evident clinical neurological finding among patients with $\mathrm{r}(10)$ syndrome. Hypotonia, sometimes associated with reduced muscle mass, has been reported among 9/20 cases, and may range from mild to severe. No other major specific focal neurologic deficit has been described to date. Nonetheless, our patient presents body rocking- and severe hair picking-like stereotypes; remarkably, case $\mathrm{n}^{\circ} 19$ presented stereotyped repetitive hand movements, pressing her palms in the midline, and stroking her thumbs [17]. Concerning psychopathological and psychiatric comorbidities, hyperactivity and mood disorders have been sporadically associated.

In our patient, EEGs showed diffuse rapid rhythms prevalent on temporo-parietal regions of both sides, and posterior slowing. No febrile or non-febrile seizures were documented by history taking or EEGs. EEG and epileptological aspects of $r(10)$ syndrome have not been studied extensively to date. Febrile seizures have been reported in $3 / 20$ cases, with a normal EEG in two cases. None of those patients developed epilepsy. Non-febrile, treatment-resistant seizures have been described in one case at 40 days of life; seizures were time-linked to progressive renal failure, which led the patient to death during his third month of life. No associated EEG finding was reported [12]. EEG abnormalities were described only in one patient (case $n^{\circ} 6$ ), reported as the presence of slow waves in occipital regions, associated with high voltage, diffuse fast activity and paroxysmal generalized slow waves [6]. Seizures were not reported for this patient.

Brain MRI disclosed in our patient dysplastic cerebellum with hypoplastic vermis, pontine hypoplasia, hypoplastic corpus callosum and lateral brain ventricle abnormalities. As for previously described patients, one was studied with a brain MRI and five with a brain CT scan. The brain MRI and 4/5 brain CTs were normal, whereas case $n^{\circ} 18$ presented a posterior fossa malformation described as Dandy-Walker variant [14]. Dandy-Walker variant is a rare congenital intracranial malformation, comprising the spectrum of abnormalities of the posterior fossa, characterized by cystic posterior fossa mass and variable hypoplasia of the cerebellar vermis, without enlargement of the posterior fossa [25]. To the best of our knowledge, our patient represents the first report of neuroradiological MRI findings in an $\mathrm{r}(10)$ chromosome syndrome. The multiple and complex brain abnormalities detected using the MR scans are probably the consequence of loss of protein-coding genes involved in the local proliferation, migration and/or differentiation of the nervous tissue, concerning in particular the structures located in the posterior cranial fossa.

Our patient presents an approximately $4.1 \mathrm{Mb}$ deletion in $10 \mathrm{p}$ and $8.2 \mathrm{Mb}$ deletion in $10 q$, affecting several protein-coding genes. A number of these genes have been previously associated with DD/ID, such as ZMYND11, EBF3, DIP2C, PRR26, and IDI2 [16,17].

ZMYND11 (Zinc finger MYND domain containing protein 11), encompassed by the 10 p15 deletion in our patient, acts as a transcriptional repressor. Haploinsufficiency of 
ZMYND11 is believed to play the main role in chromosome 10p15.3 microdeletion syndrome, a condition characterized by ID/DD, particularly affecting speech, craniofacial dysmorphism, hypotonia and seizures [26]. An association with behavioral abnormalities has been frequently reported, including aggressive behaviors, attention deficit, hyperactivity, and impulsivity and autistic traits [27]. Documented brain MRI abnormalities in these patients include cortical atrophy, pachygyria, periventricular leukomalacia and delayed myelination [28].

EBF3 (Early B Cell Factor 3), a gene involved in the deletion identified in our patient in $10 \mathrm{q} 26$, has a possible role in neuronal differentiation and maturation. A series of interstitial deletions affecting many genes and including EBF3 has been described in patients with ID/DD. More specifically, EBF3 point mutations were reported to cause a condition named Hypotonia, Ataxia, and Delayed Development Syndrome (HADDS). A small number of patients with HADDS present cerebellar vermian hypoplasia [29]. Notably, a recent report describes a patient with a small deletion affecting almost exclusively EBF3, clinically overlapping patients with larger deletions [30].

These considerations indicate that haploinsufficiency of ZMYND11 and EBF3 are likely the major drivers in determining the $\mathrm{r}(10)$ syndrome phenotype in this patient with a complex neurological involvement, characterized by ID, DD, hypotonia, behavioral abnormalities and MRI anomalies.

\section{Conclusions}

This report represents the first description of brain MRI alterations in a patient with $\mathrm{r}(10)$ syndrome. The neurological and neuroradiological findings here reported expand the clinical spectrum of $r(10)$ syndrome and are likely associated with haploinsufficiency of ZMYND11 and/or EBF3. These findings provide further support of genotype-phenotype correlations in $\mathrm{r}(10)$ syndrome, and further descriptions of patients with this condition may help the recognition, management and definition of their global clinical spectrum.

Author Contributions: Conceptualization, D.M.C., J.P. and H.A.S.M.; methodology, D.M.C. and C.G.; investigation and resources: L.M., D.M.C., C.G., C.L. and H.A.S.M.; data curation, J.P.; writingoriginal draft preparation, J.P., C.G., D.M.C.; writing-review and editing, C.G., C.L., H.A.S.M., L.M. and D.M.C.; project administration, D.M.C. All authors have read and agreed to the published version of the manuscript.

Funding: This research received no external funding.

Institutional Review Board Statement: The study was conducted according to the guidelines of the Declaration of Helsinki. Ethical review and approval were waived for this study because, according to the policy of the referral Center, the sole obtained written informed consent from the parents (legal caretakers) of the patient was necessary to publish case reports.

Informed Consent Statement: Written informed consent has been obtained from the parents (legal caretakers) of the patient to publish this paper.

Data Availability Statement: The data that support the findings of this study are available from the corresponding author upon reasonable request.

Acknowledgments: The authors also wish to thank the patient's family members for their cooperation in providing the medical data necessary for this publication.

Conflicts of Interest: The authors declare no conflict of interest.

\section{References}

1. Lansky, S.; Daniel, W.; Fleiszar, K. Physical retardation is associated with ring chromosome mosaicism: 46, XX,r(10)/45, XX,10 minus. J. Med. Genet. 1977, 14, 61-63. [CrossRef]

2. Sparkes, R.S.; Ling, S.M.; Muller, H. Ring 10 chromosome: 46,XX,r10(p15q26). Qual. Life Res. 1978, 43, 341-345. [CrossRef] [PubMed]

3. Fryns, J.P.; De Boeck, K.; Jaeken, J.; Berghe, H.V.D. Malformative syndrome associated with a ring 10 chromosome and a translocated 10q/19 chromosome. Qual. Life Res. 1978, 43, 239-244. [CrossRef] [PubMed] 
4. Simoni, G.; Rossella, F.; Visconti, G.; Piria-Schwarz, C. Ring chromosome 10 Associated with multiple congenital malformations. Qual. Life Res. 1979, 51, 117-121. [CrossRef] [PubMed]

5. Tsukino, R.; Tsuda, N.; Dezawa, T.; Ishii, T.; Koike, M. Ring chromosome 10: 46,XX,r(10)(p15->q26). J. Med. Genet. 1980, 17, 148-151. [CrossRef]

6. Michels, V.V.; Driscoll, D.J.; Ledbetter, D.H.; Riccardi, V.M.; Opitz, J.M. Phenotype associated with ring 10 chromosome: Report of patient and review of literature. Am. J. Med. Genet. 1981, 9, 231-237. [CrossRef] [PubMed]

7. Serville, F.; Briault, R.; Taillemite, J.L.; Despoisse, S.; Cotoni, P.; Broustet, A. Chromosome 10 en anneau: 46,XX,r(10)(p15q26) [Ring chromosome 10: 46,XX,r(10)(p15q26)]. Ann. Genet. 1982, 25, 168-171.

8. Nakai, H.; Adachi, M.; Katsushima, N.; Yamazaki, N.; Sakamoto, M.; Tada, K. Ring chromosome 10 and its clinical features. J. Med. Genet. 1983, 20, 142-144. [CrossRef]

9. Kondo, I.; Shimakura, Y.; Hirano, T.; Kaneko, M.; Yabuta, K. Ring chromosome 10 syndrome: Case report and the possibility of clinical diagnosis. Clin. Genet. 1984, 25, 196-200. [CrossRef]

10. Shapiro, S.D.; Hansen, K.L.; Pasztor, L.M.; DiLiberti, J.H.; Jorgenson, R.J.; Young, R.S.; Moore, C.M.; Opitz, J.M.; Reynolds, J.F. Deletions of the long arm of chromosome 10. Am. J. Med. Genet. 1985, 20, 181-196. [CrossRef]

11. Kishi, K.; Ikfuchi, T.; Yamamoto, K.; Tonomura, A.; Sakurada, N.; Satoh, Y. Report of a patient with a ring chromosome 10: mos45,XY,-10/46,XY/46,XY,r(10) (p15.3q26.3). J. Hum. Genet. 1985, 30, 233-238. [CrossRef]

12. Calabrese, G.; Franchi, P.G.; Stuppia, L.; Mingarelli, R.; Rossi, C.; Ramenghi, L.A.; Marino, M.; Morizio, E.; Peila, R.; Antonucci, A. A newborn with ring chromosome 10, aganglionic megacolon, and renal hypoplasia. J. Med. Genet. 1994, 31, 804-806. [CrossRef] [PubMed]

13. Concolino, D.; Iembo, M.; Marotta, R.; Rossi, E.; Moricca, M.; Giglio, S.; Strisciuglio, P. Ring chromosome 10 (p15q26) in a patient with unipolar affective disorder, multiple minor anomalies, and mental retardation. Am. J. Med. Genet. 2003, 123A, $201-203$. [CrossRef]

14. Guilherme, R.S.; Meloni, V.F.A.; Kim, C.A.; Pellegrino, R.; Takeno, S.S.; Spinner, N.B.; Conlin, L.K.; Christofolini, D.M.; Kulikowski, L.D.; Melaragno, M.I. Mechanisms of ring chromosome formation, ring instability and clinical consequences. BMC Med. Genet. 2011, 12, 171. [CrossRef]

15. Christopoulou, G.; Tzetis, M.; Konstantinidou, A.; Tsezou, A.; Kanavakis, E.; Kitsiou-Tzeli, S.; Velissariou, V. Clinical and molecular description of a fetus in prenatal diagnosis with a rare de novo ring 10 and deletions of $12.59 \mathrm{Mb}$ in 10p15.3-p14 and 4.22Mb in 10q26.3. Eur. J. Med. Genet. 2012, 55, 75-79. [CrossRef]

16. Guilherme, R.S.; Kim, C.A.; Alonso, L.G.; Honjo, R.S.; Meloni, V.A.; Christofolini, D.M.; Kulikowski, L.D.; Melaragno, M.I. Ring chromosome 10: Report on two patients and review of the literature. J. Appl. Genet. 2012, 54, 35-41. [CrossRef]

17. Čiuladaitè, Ž.; Burnytė, B.; Vansevičiūtè, D.; Dagytè, E.; Kučinskas, V.; Utkus, A. Clinical, cytogenetic and molecular study of a case of ring chromosome 10. Mol. Cytogenet. 2015, 8, 29. [CrossRef] [PubMed]

18. Kosztolányi, G. The genetics and clinical characteristics of constitutional ring chromosomes. J. Assoc. Genet. Technol. 2009, 35, 44-48.

19. Bertino, E.; Spada, E.; Occhi, L.; Coscia, A.; Giuliani, F.; Gagliardi, L.; Gilli, G.; Bona, G.; Fabris, C.; De Curtis, M.; et al. Neonatal Anthropometric Charts: The Italian Neonatal Study Compared With Other European Studies. J. Pediatr. Gastroenterol. Nutr. 2010, 51, 353-361. [CrossRef] [PubMed]

20. Online Mendelian Inheritance in Man (OMIM). Available online: https:/ / www.omim.org (accessed on 19 September 2021).

21. DECIPHER. Available online: https:/ / www.deciphergenomics.org (accessed on 19 September 2021).

22. GeneCards. Available online: https://www.genecards.org (accessed on 19 September 2021).

23. Jandeaux, C.; Kuchcinski, G.; Ternynck, C.; Riquet, A.; Leclerc, X.; Pruvo, J.-P.; Soto-Ares, G. Biometry of the Cerebellar Vermis and Brain Stem in Children: MR Imaging Reference Data from Measurements in 718 Children. Am. J. Neuroradiol. 2019, 40, 1835-1841. [CrossRef]

24. Garel, C.; Cont, I.; Alberti, C.; Josserand, E.; Moutard, M.; Le Pointe, H.D. Biometry of the Corpus Callosum in Children: MR Imaging Reference Data. Am. J. Neuroradiol. 2011, 32, 1436-1443. [CrossRef] [PubMed]

25. Rajput, R.; Mishra, S.; Ahlawat, P.; Yadav, P.K. Dandy-Walker variant with precocious puberty: A rare association. BMJ Case Rep. 2018, 11, e226281. [CrossRef] [PubMed]

26. DeScipio, C.; Conlin, L.; Rosenfeld, J.; Tepperberg, J.; Pasion, R.; Patel, A.; McDonald, M.T.; Aradhya, S.; Ho, D.; Goldstein, J.; et al. Subtelomeric deletion of chromosome 10p15.3: Clinical findings and molecular cytogenetic characterization. Am. J. Med. Genet. Part A 2012, 158A, 2152-2161. [CrossRef]

27. Yates, T.M.; Drucker, M.; Barnicoat, A.; Low, K.; Gerkes, E.H.; Fry, A.E.; Parker, M.J.; O’Driscoll, M.; Charles, P.; Cox, H.; et al. ZMYND11 -related syndromic intellectual disability: 16 patients delineating and expanding the phenotypic spectrum. Hum. Mutat. 2020, 41, 1042-1050. [CrossRef] [PubMed]

28. Tumiene, B.; Čiuladaitė, Ž.; Preikšaitienè, E.; Mameniškienė, R.; Utkus, A.; Kučinskas, V. Phenotype comparison confirms ZMYND11 as a critical gene for 10p15.3 microdeletion syndrome. J. Appl. Genet. 2017, 58, 467-474. [CrossRef] [PubMed] 
29. Harms, F.L.; Girisha, K.M.; Hardigan, A.A.; Kortüm, F.; Shukla, A.; Alawi, M.; Dalal, A.; Brady, L.; Tarnopolsky, M.; Bird, L.; et al. Mutations in EBF3 Disturb Transcriptional Profiles and Cause Intellectual Disability, Ataxia, and Facial Dysmorphism. Am. J. Hum. Genet. 2016, 100, 117-127. [CrossRef] [PubMed]

30. Lopes, F.; Soares, G.; Gonçalves-Rocha, M.; Pinto-Basto, J.; Maciel, P. Whole Gene Deletion of EBF3 Supporting Haploinsufficiency of This Gene as a Mechanism of Neurodevelopmental Disease. Front. Genet. 2017, 8, 143. [CrossRef] 